\title{
Environmental Regulation and Industry Location in Europe
}

\author{
Abay Mulatu • Reyer Gerlagh · Dan Rigby • \\ Ada Wossink
}

Accepted: 3 September 2009 / Published online: 23 September 2009

(C) The Author(s) 2009. This article is published with open access at Springerlink.com

\begin{abstract}
This paper estimates the effect of environmental regulation on industry location and compares it with other determinants of location such as agricultural, education and R\&D country characteristics. The analysis is based on a general empirical trade model that captures the interaction between country and industry characteristics in determining industry location. The Johnson-Neyman technique is used to fully explicate the nature of the conditional interactions. The model is applied to data on 16 manufacturing industries from 13 European countries. The empirical results indicate that the pollution haven effect is present and that the relative strength of such an effect is of about the same magnitude as other determinants of industry location. A significant negative effect on industry location is observed only at relatively high levels of industry pollution intensity.
\end{abstract}

Keywords Pollution haven hypothesis - Comparative advantage $\cdot$ Industry location

\section{Introduction}

Does environmental regulation have a significant negative impact on industry location? This question is at the heart of the trade and environment debate. A positive answer to this question might give grounds to concerns regarding a host of interrelated issues: the emergence of 'pol-

We wish to thank John A. List, two anonymous referees, participants of the 16th and the 17th EAERE Annual Conferences, Pierre Picard and Cees Withagen for helpful comments.

\footnotetext{
A. Mulatu $(\bowtie)$

Economics, LMBS, London Metropolitan University, 84 Moorgate, London EC2M 6SQ, UK e-mail: a.mulatu@londonmet.ac.uk

R. Gerlagh · D. Rigby · A. Wossink

Economics, School of Social Sciences, University of Manchester, Manchester, UK

R. Gerlagh

Tilburg University,

Tilburg, The Netherlands
} 
lution havens' in environmentally lax countries, harm to competitiveness in environmentally strict countries, and a consequent attempt by jurisdictions to undercut each other's environmental standards. Such issues have served as an additional impediment to the conclusion of the latest round of WTO trade liberalization that started in Seattle in 1999 (Ederington et al. 2004; Wolfe 2004). Industrialists in the EU are also worried about the extent to which the EU Emissions Trading Scheme impairs their competitiveness (Reinaud 2004). Similarly in the US, competitiveness concerns were raised during the debate on the impact of North American Free Trade. Critics argued that differential environmental standards across Canada, Mexico and US would result in massive capital flight to Mexico which would cause more overall pollution.

These issues have received considerable attention in the academic literature and much of the studies are collected under the denominator of the so-called Pollution Haven Hypothesis (PHH). ${ }^{1}$ This hypothesis purports that changes in environmental regulation results in a relocation of dirty goods production from countries with stringent environmental regulation to those with lax environmental regulation. While the hypothesis is intuitively plausible, reviews of the empirical literature have concluded that the evidence is mixed or that the correlation between environmental regulation and industry performance is weak (see, for e.g., Copeland and Taylor 2003; Jaffe et al. 1995; Raspiller and Riedinger 2008). Supported by evidence from a meta-analysis of 11 studies, Jeppesen et al. (2002) show how empirical specification, data issues, definition of the regulatory variable, and the control variables included all have a considerable influence on the empirical results. In particular they find that the smaller the geographical area of study, the larger the estimated influence of regulation. They also find that the often reported results that pollution and non-pollution intensive industries are affected similarly may be a repercussion of pooling industries that are in fact heterogeneous. Taylor (2004) has further pointed out that empirical work on the PHH has been troubled by, among other things, the fact that researchers at times mistake a pollution haven effect for the pollution haven hypothesis. Pollution haven effects occur if differences in the levels of environmental regulatory stringency affect the inter-jurisdictional distribution of polluting industries. Such effects, if present, are only one determinant of industry location. The PHH however postulates that the interaction between environmental regulation and pollution intensity is the most important determinant for firm location, or at least more important than other determinants, such as the availability of capital and skilled labor. This leads-it is hypothesised - to a "race to the bottom", where jurisdictions have incentives to lower environmental standards to maintain or increase their share of those industries most affected by such standards.

The differential stringency of environmental regulation is only one of several motives for firms' location choices and hence there have been recent calls in the literature for empirical work weighing the relative strength of these different motives ${ }^{2}$ (Taylor 2004). Our aim is to present a way of undertaking such an assessment. The analysis in this paper complements those of Becker and Henderson (2001), Greenstone (2002), and List and McHone (2000) who have documented evidence of the pollution haven effect using county level plant data for the US and New York state, respectively. Becker and Henderson study four pollution intensive industries, Greenstone uses dummies for dirty as opposed to clean industries,

\footnotetext{
1 See, for example, a recent edited volume dedicated to the Pollution Haven Hypothesis (Fullerton 2006).

2 Such calls also remind us of a seemingly trivial but a more general point about hypothesis testing. Strictly speaking, the question of how accurate a hypothesis is necessitates an explicit statement of an alternative hypothesis with which the maintained hypothesis is to be compared. In the absence of an alternative hypothesis, normal statistical methods of inference are not applicable and rejection/acceptance of the maintained hypotheses is a matter of mere judgment (Leamer 1984, pp. 45-47).
} 
and List and McHone compare the location decisions of polluting new plants in attainment (stringent) and non-attainment (lax) counties. ${ }^{3}$ We propose an alternative approach by explicitly including a continuous variable of pollution intensity per industries so that we can address the question: 'how polluting must an industry be to be adversely affected by environmental regulation?', a refinement of the typical question in the literature: 'are polluting industries affected by environmental regulation?'. Also, we include other determinants of firm location so that we can compare the different determinants and distinguish between the pollution haven hypothesis and the pollution haven effect. In this sense, this paper also complements Levinson and Taylor's (2008) study which, like this paper, uses a continuous measure of pollution intensity as an explanatory variable but it does not compare environmental policy with other location determinants. Our paper further complements the paper by Cole et al. (2005) which analysed US's revealed comparative advantage to examine the hypothesis of a decline in US's specialisation in pollution-intensive industries. The authors did not find a support for the hypothesis and gave the explanation that such industries were also intensive in physical and human capital which US is endowed with relatively well. ${ }^{4}$

Our paper contributes to the literature in three ways. First, we integrate two strands of literature; one from economic geography and one from environmental economics. We employ a general empirical trade model that has recently appeared in the new economic geography literature but has not previously been used in the pollution haven literature. The model analyzes the joint role of country and industry characteristics in determining industry location. Specifically, it estimates how high and low levels of country characteristics interact with high and low intensities of the corresponding industry attributes in location decisions. The model allows us to supplement and expand recent findings in the empirical PHH literature that the impact of environmental regulation tends to be "heterogeneous both spatially and across industry" (Millimet and List 2004. p. 261; Mulatu et al. 2004). The model complements the analyses by Cole and Elliott (2003a) and Chintrakarn and Millimet (2006) as it uses explicit variables for environmental policy and pollution intensity as a driver of location, rather than studying the pollution haven effect indirectly by regressing emission levels against trade intensity, income, the capital/labor ratio, and their various interaction effects.

Second, we elaborate on the interpretation of the conditional effects associated with the interactive terms in our empirical model. The most common method for probing interactive effects is to test significance of coefficients at specific levels of the predictors. In our case, the standard approach would be to test significance for location dependence on environmental policy stringency, given a specific level of the industry's pollution intensity. We, more broadly, present the dependence relation over the whole range of industry's pollution intensity and employ the Johnson-Neyman technique to calculate regions of significance and confidence bands for evaluating the conditional effects.

\footnotetext{
3 Our paper also complements papers in a related strand of the literature such as List and Co (2000); Keller and Levinson (2002) and Xing and Kolstad (2002) who focus, respectively on US inbound and outbound FDI. Each of these papers compares regression results for dirty and clean industries (or all manufacturing) and obtains some evidence of the pollution haven effect.

4 Broadly speaking, our paper is also related to that of Cole and Elliott (2003b) which distinguishes between two somewhat different questions examined, respectively in the Heckscher-Ohlin and in the 'new' trade models: does environmental regulation affect net exports of pollution-intensive goods?; and does environmental regulation, like the traditional factor endowments, play a role in the composition of trade? Again, however, the paper does not compare environmental policy with other location determinants.
} 
Third, as we apply our approach to data on manufacturing industries from European countries, the analysis focuses on intra-EU heterogeneity and its consequences for firm location. The dataset includes pollution intensive industries such as Industrial Chemicals and 'clean' industries such as Radio, TV \& Communication and covers countries with stringent environmental regulation such as Finland and Sweden as well as countries with relatively lax environmental regulation such as Greece and Belgium. A disadvantage of a narrow country selection is lack of variability in country characteristics, which will make the empirical tests harder to prove significance. On the other hand, an advantage of a narrow country sample is that it reduces the possibilities of omitted variable bias, as these countries share much of their history, geography, and many institutions. There is no need to suspect colonial history, climate conditions, or large differences in cultural attitudes to affect the results. In general, working with a homogeneous sample for an empirical study makes it hard to find significant results, but if these are found, they are more reliable. In previous studies, it has been shown that environmental policy within the EU is not homogeneous: within the EU-15 substantial differences exist (Pellegrini and Gerlagh 2006a). Furthermore, we have to bear in mind that for countries in the EU-15, still more than half of manufacturing imports and exports remains within this group of countries, so that policy's effects on industry location is of substantial importance. 5

The results indicate that the pollution haven effect can be uncovered, and that the relative strength of such an effect is of about the same magnitude as other determinants of industry location. Further investigation of the conditional effects indicates that a significant negative effect on industry location is observed only at relatively high levels of pollution intensity. Thus, the focus on environmental stringency in this literature is only half the story: both stringency of environmental regulation and industry pollution intensity matter. The findings we report suggest that for the $\mathrm{PHH}$ literature the interaction between the differential stringency of environmental regulation and differences in industry pollution intensity is an essential element.

The rest of the paper is organized as follows. Section 2 presents the econometric model. Section 3 describes the data. Section 4 discusses the empirical results and Sect. 5 concludes.

\section{Theory and Empirical Model}

The model aims to investigate the relevance of various factors in industry's location. In particular, we want to know why some countries attract a high share of certain industries, while other countries have a much lower share. Formally, we search for the determinants of the share of country $i$ in the total manufacturing production of industry $k$, that is $s_{i, k}$ defined as $s_{i k}=z_{i, k} / \sum_{i^{\prime}} z_{i^{\prime}, k}$, where $z_{i, k}$ measures the size of industry $k$ in country $i$, and the country label with prime $\left(i^{\prime}\right)$ is used to sum over all countries.

Trade theorists' discussions of industry location are informed by two strands of literature. Comparative advantage arguments based on the role of factor endowments can be derived from Heckscher-Ohlin (HO) models. Recent theoretic work has extended the standard HO models to accommodate environmental factors where cross-country differences in the stringency of environmental regulation play a role in trade patterns. (e.g. Antweiler et al. 2001; Copeland and Taylor 1994, 1995, 2003).

\footnotetext{
$\overline{5}$ We notice also that much of previous literature has studied competition between US states, and between US and Canada.
} 
New economic geography (NEG), by contrast, stresses the importance of increasing returns, market access and upstream and downstream linkages. NEG predicts that while activity will be dispersed when transport costs are either 'very high' or 'very low', clustering of industries occur when transport costs are 'intermediate'. 6 The HO and NEG theories should be regarded as complementary and their relative importance for industrial location outcomes is thus an empirical issue.

Recently, Midelfart-Knarvik et al. (2000b) developed an empirical model for the location of European industry that incorporates both types of effects, i.e. comparative advantage and market access. They estimate a model that takes account of the HO arguments by relating the factor intensities of industries to the factor endowments of countries. The NEG story is captured by examining how the share of intermediates in costs, the share of sales to industrial users, and scale economies interact with market potential in determining location.

We extend Midelfart-Knarvik et al. (2000b) econometric model and include environmental factors. Countries are heterogeneous in various characteristics such as endowments of natural resources and skilled labor, and proximity to markets. We add to these country characteristics the relative stringency of environmental regulation. Similarly, industries differ in their various attributes such as the intensity of use of production factors like skilled labor, and their reliance on intermediate inputs. We add to these attributes the pollution intensity of the industry. In equilibrium we expect that industries that highly value a regional characteristic locate there. All else equal, a technology intensive industry will locate in a region with abundant skilled labor, while pollution intensive industries will be attracted to countries with a relatively lax environmental regulation. In the context of the $\mathrm{PHH}$ literature, the relevant empirical question is how strong the interaction is between environmental regulation and pollution intensity, relative to the interaction between other country and industry characteristics.

Central in the model are the potential interaction channels, indexed $j$. For each interaction channel, we have a vector of associated country characteristics $x^{j}$, and a vector of associated industry attributes $y^{j}$. For the skilled-labor interaction channel, $x^{j}$ measures countries' skilled labor abundance, while $y^{j}$ measures the industries' skilled labor intensity. For the pollution interaction channel, $x^{j}$ measures the countries' stringency of environmental regulation (or its inverse, the laxity), while $y^{j}$ measures the industries' pollution intensity. For each interaction channel, there is a neutral country characteristic level $\chi^{j}$, also referred to as a cut off point, such that a country with this characteristic does not specifically attract industries with high or low levels for the associated industry attribute. Similarly, there is a neutral industry attribute level $\gamma^{j}$, or cut off point, such that an industry with this attribute level does not consider the associated country-characteristic in the selection of its location. Using these parameters, Midelfart-Knarvik et al.'s model can be written as a reduced form equation:

$$
\ln \left(s_{i, k}\right)=c+\alpha \ln \left(\text { pop }_{i}\right)+\sum_{j} \beta^{j}\left(x_{i}^{j}-\chi^{j}\right)\left(y_{k}^{j}-\gamma^{j}\right)+\varepsilon_{i, k},
$$

where $\operatorname{pop}_{i}$ is the population living in country $i, \alpha$ is a scale coefficient, and $\beta^{j}$ measures the strength of interaction effect $j$. The country characteristics and industry attributes are chosen such that the interaction coefficients $\beta^{j}$ are expected to be positive. Expanding the equation we obtain the estimating equation as follows:

${ }^{6}$ See, e.g., Krugman and Venables (1995). 


$$
\ln \left(s_{i, k}\right)=c^{\prime}+\alpha \ln \left(\text { oop }_{i}\right)+\sum_{j}\left(\beta^{j} x_{i}^{j} y_{k}^{j}-\gamma^{\prime j} x_{i}^{j}-\chi^{\prime j} y_{k}^{j}\right)+\varepsilon_{i, k},
$$

where $\gamma^{\prime j}=\beta^{j} \gamma^{j}, \chi^{\prime j}=\beta^{j} \chi^{j}$, and $c^{\prime}=c+\sum_{j} \beta^{j} \chi^{j} \gamma^{j}$. After we have estimated $\beta, \chi^{\prime}$, and $\gamma^{\prime}$ from (2) we can inverse the procedure and calculate the parameters $\chi$ and $\gamma$ in (1). ${ }^{7}$

We specify seven interaction channels. The first three interaction channels are associated with the traditional HO trade model. ${ }^{8}$ The fourth interaction channel is the environmental variable which is the main concern in this paper. The last three interaction channels represent the NEG concerns of the model, namely the pull of centrality interacting with scale economies, and forward and backward linkages. In full, the interaction channels are: (i) Agricultural production as percentage of GDP times industry agricultural input intensity; ${ }^{9}$ (ii) Secondary \& higher education as percentage population times industry skilled labor intensity; (iii) Researchers \& Scientists as percentage of labor force times industry R\&D intensity; (iv) Environmental standard laxity times industry pollution intensity; (v) Market potential times industry intermediate input use; (vi) Market potential times industry sale to industry; and finally (vii) Market potential times industry average plant size. The main hypothesis regarding the new economic geography interaction variables is that a firm's location decision involves consideration of market access alongside production costs. ${ }^{10}$ In Table 1 we present the country characteristics and their association with the interaction channels, and the data sources. In Table 2, we present the industry attributes and their association with the interaction channels.

\section{Interactions and Regions of Significance}

Of key interest for the PHH debate is the effect of a country's characteristic on firm location. The question is whether a change in environmental policy, or in another country's characteristic, will make this country more or less attractive to firms, in general, or for specific sectors. From the location model as in Eq. (1), we can directly calculate the change in an industry's share a country attracts as dependent on a change in a country characteristic:

$$
\frac{\partial \ln \left(s_{i, k}\right)}{\partial x_{i}^{j}}=\beta^{j}\left(y_{k}^{j}-\gamma^{j}\right)=\beta^{j} y_{k}^{j}-\gamma^{\prime j} .
$$

Given a positive interaction coefficient $\beta^{j}$, it is immediately clear from Eq. (3) that the increase of characteristic $j$ in a country increases the share of industry $k$ if that industry's level of attribute $j$ exceeds the attribute's cut-off level, that is, if $y_{k}^{j}>\gamma^{j}$. An increase of a country's characteristic $j$ will repel other industries. For example, countries with lax environmental policies may attract pollution-intensive industries and repel clean industries, or stated the other way around, countries with strict environmental policies may attract clean industries and repel pollution-intensive industries. What is considered a clean or a dirty industry is determined by the cut-off value $\gamma^{j}$. An immediately obvious comparison of interest therefore is that between the industry's cut-off points $\gamma^{j}$ and the mean, maximum, and minimum

\footnotetext{
7 When different interaction effects make use of the same country characteristic or industry attribute, the calculation of the cut-off points $\chi$ and $\gamma$ becomes slightly more complicated. See notes to Table 3 .

8 Capital is ignored because of the assumption of capital mobility across Europe.

9 Following Midelfart-Knarvik et al. (2000b) the rationale for taking the variable Agricultural production as $\%$ GDP instead of the underlying conventional factor inputs such as land is that, since our concern is the pattern of manufacturing, agriculture can be considered as an exogenous measure of the 'endowment of agriculture'.

10 See, e.g., Venables (1996).
} 


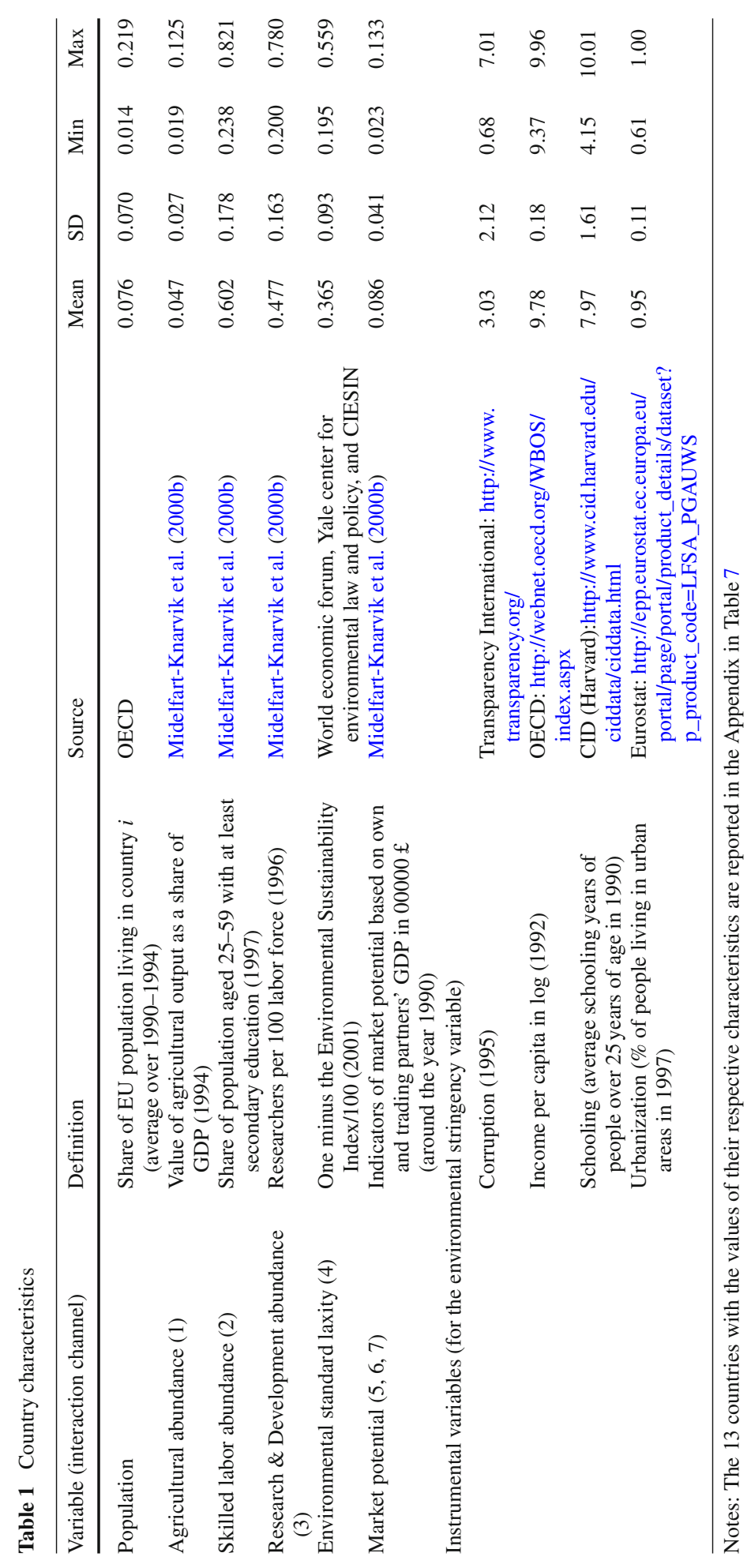




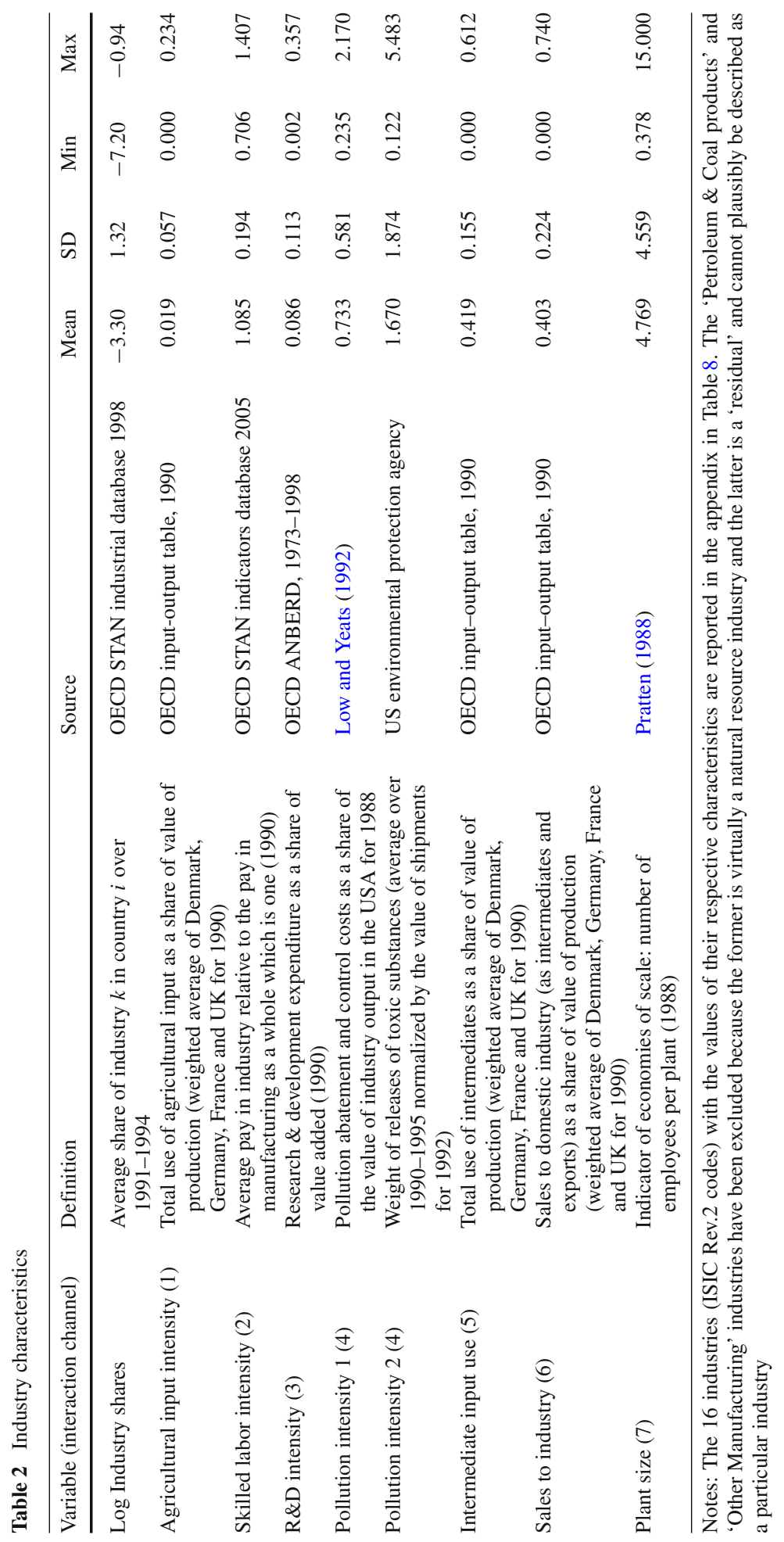


values of these industry attributes reported in Table 2 . If an industry attribute's cut-off point is close to the minimum value of that industry attribute, this means that an increase in the corresponding country characteristic will attract industry activity, for the sample of industries as a whole. If an attribute's cut-off point is close to the maximum value of that industry attribute, this means that an increase in the corresponding country characteristic will repel industry activity, for the sample of industries as a whole. If the cut-off point is in between, an increase in the associated country characteristic implies a more selective firm activity, but not necessarily an overall increase or decrease.

We notice that the country characteristics cut-off levels $\chi^{j}$ do not appear in the analysis of firm location's response to a change in country characteristics (Eq.3), and thus we will not further discuss them.

The expression in (3) also reveals that the marginal effect of a change in a country characteristic $j$ on the share of an industry located within it is proportional to the interaction coefficient $\beta^{j}$, and the difference between the industry's attribute level $y_{k}^{j}$ and the cut-off point $\gamma^{j}$. Estimation of $\beta^{j}$ and $\gamma^{j}$ therefore permits these marginal effects to be estimated. Substitution of the estimated coefficients $\hat{\beta}^{j}$ and $\hat{\gamma}^{\prime j}$ gives, for any given industry attribute level $y_{k}^{j}$, the variance of the estimated marginal effect in (3):

$$
\operatorname{var}\left[\hat{\beta}^{j}\left(y_{k}^{j}-\hat{\gamma}^{j}\right)\right]=\left(y_{k}^{j}\right)^{2} \operatorname{var}\left[\hat{\beta}^{j}\right]+\operatorname{var}\left[\hat{\gamma}^{\prime j}\right]-2 y_{k}^{j} \operatorname{cov}\left[\hat{\beta}^{j}, \hat{\gamma}^{\prime j}\right] .
$$

Thus, estimation of $\hat{\beta}^{j}$ and $\hat{\gamma}^{\prime j}$ allows us to plot the marginal effect and associated confidence interval of environmental policy on industry location, as dependent on the industry's pollution intensity. This approach of calculating regions of significance and confidence bands for evaluating conditional effects is known as the Johnson-Neyman ( $\mathrm{J}-\mathrm{N})$ technique (Huitema 1980). Clearly the J-N technique has advantages over the more common approach which would involve testing the conditional effects at designated levels of environmental stringency (e.g., high, medium, or low (Bauer and Curran 2005)).

Although the focus here is environmental (pollution intensity and the stringency of environmental regulation) the procedure and insights are general. For example, one could estimate the marginal effect of changes in a nation's level of skilled labour on its share of skill-intensive industries.

\section{Data}

We base our analysis on a one-period cross-country cross-industry sample. The sample includes 13 countries and 16 industries. The choice of the period (average of 1990-1994) was dictated by availability of most of the explanatory variables. ${ }^{11}$ Descriptions of the variables and data sources are presented in Tables 1 and 2. The discussion here is limited to some relevant issues not contained in the table and a further description of the main variables of interest in this paper, i.e. the environmental variables. Data on each of the country characteristics pertain to around the year 1990 and are obtained from Midelfart-Knarvik et al. (2000b). Input-output data (i.e. agricultural intensity, intermediate input intensity and industry sale) are constructed as (output) weighted averages of the data for Denmark, Germany, France and the UK for 1990. The environmental standard laxity variable is constructed as one minus the Environmental Sustainability Index (scaled to $[0,1]$ ) which is constructed jointly by World Economic Forum, Yale Center for Environmental Law and Policy, and Center for

11 We have also experimented with each of the five individual year values for the left hand side variable. The results are fairly similar. 
Table 3 Regression results

\begin{tabular}{|c|c|c|c|c|}
\hline \multirow[t]{2}{*}{ Dependent variable: $\ln \left(s_{i k}\right)$} & \multicolumn{4}{|l|}{ Model } \\
\hline & $\mathrm{I}$ & II & III & IV \\
\hline \multicolumn{5}{|l|}{ Size variable } \\
\hline Population & $1.04^{* * *}$ & $1.04^{* * *}$ & $1.04^{* * *}$ & $1.04^{* * *}$ \\
\hline \multicolumn{5}{|l|}{ Interaction channels $\left(\beta^{j}\right)$} \\
\hline Agricultural abundance $\times$ intensity & $31.44^{*}$ & $32.10^{*}$ & $35.16^{* *}$ & $35.22^{* *}$ \\
\hline Skilled labor abundance $\times$ intensity & 1.83 & 1.81 & 1.97 & 1.96 \\
\hline R\&D abundance $\times$ intensity & $4.04^{* *}$ & $4.18^{* *}$ & $4.66^{* *}$ & $4.78^{* *}$ \\
\hline Environmental laxity $\times$ poll. Intensity & $1.21^{* *}$ & $0.40^{* *}$ & $1.20^{* *}$ & $0.41^{* *}$ \\
\hline Market potential $\times$ Sales to industry & -5.60 & -5.67 & & \\
\hline Market potential $\times$ Intermediate input use & -4.52 & -4.18 & & \\
\hline Market potential $\times$ Plant size & 0.17 & 0.16 & & \\
\hline \multicolumn{5}{|l|}{ Country characteristics cut-off points $\left(\chi^{j}\right)$} \\
\hline Agricultural abundance & -0.02 & -0.01 & 0.01 & 0.004 \\
\hline Skilled labor abundance & 0.95 & 0.93 & 0.88 & 0.80 \\
\hline R\&D abundance & 0.16 & 0.15 & 0.45 & 0.49 \\
\hline Environmental standards laxity & 0.23 & 0.24 & 0.21 & 0.26 \\
\hline \multirow[t]{3}{*}{ Market potential } & 0.19 & 0.19 & & \\
\hline & 0.07 & 0.09 & & \\
\hline & 0.17 & 0.20 & & \\
\hline \multicolumn{5}{|l|}{ Industry attributes cut-off points $\left(\gamma^{j}\right)$} \\
\hline Agricultural input intensity & 0.46 & 0.45 & 0.42 & 0.41 \\
\hline Skilled labor intensity & 1.05 & 1.05 & 1.04 & 1.04 \\
\hline R\&D intensity & 0.03 & 0.03 & 0.04 & 0.04 \\
\hline Pollution intensity & 0.87 & 2.08 & 0.86 & 2.04 \\
\hline Sales to industry ${ }^{\mathrm{a}}$ & 0.41 & 0.41 & & \\
\hline Intermediate input use $\mathrm{e}^{\mathrm{a}}$ & 0.41 & 0.41 & & \\
\hline Plant size $\mathrm{e}^{\mathrm{a}}$ & 4.09 & 4.09 & & \\
\hline$N$ & 208 & 208 & 208 & 208 \\
\hline Adj. $R^{2}$ & 0.84 & 0.84 & 0.84 & 0.84 \\
\hline
\end{tabular}

Notes: * Significant at $10 \%$ level; ** Significant at $5 \%$ level; *** Significant at $1 \%$

a The fifth, sixth and seventh interaction effects all use the same country characteristic Market Potential. As a result, in Eq. (2), $x^{5}=x^{6}=x^{7}$, consequently we cannot estimate $\gamma^{\prime 5}$ separately from $\gamma^{\prime 6}$ and $\gamma^{\prime 7}$ to identify the cut off points. Since the first two associated industry attributes (sales, intermediate input use) are of about the same size, while the third attribute (plant size) is about ten times larger (Table 2), we impose $\gamma^{5}=\gamma^{6}$ and $\gamma^{7}=10 \cdot \gamma^{5}$, and this condition enables us to identify the cut off points

International Earth Science Information Network, Columbia University. This index refers to the year 2001 and is based on a total of 67 underlying variables (such as environmental regulatory stringency, environmental regulatory innovation and number of EIA guidelines). ${ }^{12,13}$

\footnotetext{
12 This index is also used in Javorcik and Wei (2004).

13 We have also experimented with an alternative measure of environmental regulation stringency from the Global Competitiveness Report 2001-2002, published by the World Economic Forum. The main results using
} 
The time frame of the environmental sustainability index raises the issue of endogeneity, as nations' environmental policy might be driven by the industries located within them. It can be argued that environmental policy is unlikely to vary dramatically annually, or at least the ranking across the sample, in the time period considered here. However, to check for an endogeneity problem, we carry out a robustness analysis where we use corruption in 1995 , income in 1992, urbanization in 1997, and schooling in 1990 as instruments (based on Pellegrini and Gerlagh 2006a). The results are reported in Table 11 and fully confirm the results of the base analysis. We do not use the instruments for the main analyses in this paper, as this would make our discussion of the implications of real versus possible counterfactual environmental policies unnecessarily opaque.

We use two alternative measures of pollution intensity. The first measure is taken from Low and Yeats (1992) who provide estimates of pollution abatement and control costs as a share of the value of industry output in the USA for the year 1988. The second measure is based on the Toxic Release Inventory (TRI) data compiled by the US Environmental Protection Agency. The TRI data catalogues releases of various types of emissions into air, water, land and underground for each manufacturing industry group in the US. Such emissions measured by weight for the year 1990-1995 are averaged and normalized by the value of industry shipments for the year $1992 .{ }^{14}$ The full data on all the explanatory variables are reported in the appendix in Tables 7 and 8.

\section{Results and Discussion}

Table 3 reports the results of the Ordinary Least Squares Robust Error estimation of Eq. (1) for four different specifications. Models I and II use the full model with the NEG and HO interaction channels, with two different specifications for the industry pollution intensity attribute. Models III and IV use only the first four HO variables, again with alternative measures of the industry pollution intensity attribute. Models I and III use abatement costs, and Models II and IV use industry emissions, as the measure of pollution intensity.

For all models, the estimated coefficients for the interaction channels $\beta$ reported in Table 3 are expected to have positive signs. The estimations confirm the expectations for the HO channels. Thus, industries with large inputs from agriculture tend to locate in countries with a

Footnote 13 continued

this measure of stringency are reported in the Appendix (Table 9 being the equivalent of Table 3 and Table 10 the equivalent of Table 5). These results confirm our finding of significant positive coefficients for the interaction channel (with the two alternative pollution intensity variables discussed below) but gave a wider uncertainty interval for the marginal effects per industry as in Eq. (4). We have further considered other measures of stringency. One measure is reported in van Soest et al. (2006). This measure is based on the shadow price of energy and is calculated for two sectors: one for primary metals sector and another for food and beverages. The coefficient of correlation between each of these two and our measure, ESI are, respectively, -0.26 and 0.41 . Whatever the merit of these two indicators of stringency, they are available for only 9 out of the 13 countries in our sample. There are four more indicators that appeared in the literature and as argued by van Soest et al. (2006) each has shortcomings as a measure of stringency. A practical problem is that most of them are only available for a subset of our countries. Nonetheless each is positively correlated with our measure, ESI.

14 Our second measure of pollution intensity is also used in Javorcik and Wei (2004). These authors also employ an alternative measure of pollution intensity similar to our first measure, i.e. based on pollution abatement expenditure. A third measure that we considered is based on Greenhouse Gas Emissions in UK manufacturing industries (available from UK Environmental Accounts). We normalised this data for 1990 by the value of output of the respective industry in order to proxy intensity. The resulting measure is positively correlated with our two measures (correlation coefficients of 0.57 and 0.34 , respectively). However, we did not pursue this alternative measure because, unlike the other two measures, it is based on GHG emissions only. 
large agricultural industries, industries with above-average valued labor input tend to locate in countries with an above-average skilled population, R\&D intensive industries tend to locate in $R \& D$ rich countries, and indeed, industries that are relatively more pollution intensive (such as Industrial Chemicals and Drugs \& Medicines) are attracted to countries which have relatively lax environmental standards. We note that although the $\beta$ coefficient for skilled labour is not significant in Table 3, we show later that the level of skilled labour supply has a significant positive effect on the share of the most skilled-labor intensive industry (see Table 5).

The additional three NEG variables, however, do not all have the expected sign and are insignificant. A formal test of comparing the full model with the model of only the HO variables (including the environmental variable) amounts to a test of whether the estimates of the coefficients of the NEG variables are jointly zero. If so, the parsimonious model is preferred. The $F$ statistic $(F[7,187])$ for the hypothesis of an HO model is 1.62 for Model I and 1.81 for Model II which, given a critical value at the 5\% significance level of 2.01, indicates that the null hypothesis that the HO model is appropriate cannot be rejected. We therefore omit the NEG variables and confine further analysis to Models III and IV. By comparing models I with III and II with IV, we see that the strength of the pollution interaction effect is robust with respect to the inclusion or exclusion of the NEG channels. For all other interaction effects, we also find robust results. This insignificance of the NEG variables contrasts with the finding of Midelfart-Knarvik et al. (2000a) who report significant estimates for the market potential variable but their findings do not seem to be particularly robust as can be seen from Midelfart-Knarvik et al. (2000a).

Using Eq. (3), a comparison of the industry's cut-off points with the mean value informs us on the effect of the country characteristic on the average industry within our sample. The first remarkable finding is that the cut-off point for agricultural intensity is above the maximum attribute level observed in the sample. Thus, as Eq. (3) predicts, for all industries within the sample, the industry share in a country decreases as agriculture's contribution to that country's GDP increases. For the food processing industry (the most intensive industry), the decrease is relatively modest, whereas for the non-ferrous metal industry (the least agriculture-intensive industry), the effect is very large. An explanation for this finding is that, in general, manufacturing and agriculture are strongly negatively correlated. For all other factor inputs, the cut-off point is between the minimum and maximum industry attribute level, signifying that more intensive industries are attracted by the more resource abundant countries, while less intensive industries typically locate in countries that are less resource abundant for that specific resource. For skilled labor, the cut-off point (1.04) is below the industry's attribute's mean (1.08), which means that within our sample, on average, industries are attracted by countries with higher levels of skilled labor. Regarding R\&D intensity, the cut-off point (0.04) is also below the mean (0.087) so that, on average, firms are attracted by R\&D-rich countries. For both measures of pollution intensity, the cut-off points (0.86 and 2.04) are above the sample means ( 0.73 and 1.67$)$ meaning that, on average, firms are not attracted by lax environmental policies, or stated inversely, are not deterred by stricter environmental policy. This result is a first indication that strict environmental policy does not deter manufacturing industries in general. That is, even though the most pollution-intensive industries show a significant smaller share in countries with strict environmental policies, on average, within our sample, industries do not prefer to locate in countries with lax environmental policies.

The coefficients reported in Table 3 do not allow one to assess the relative importance of the various interaction channels. To allow such an assessment of the relative importance of the various interaction effects, the estimated cut-off points from Eq. (2), as presented in 
Table 4 Standardized coefficients of interaction effects at the jointly estimated cut off points

\begin{tabular}{lll}
\hline & \multicolumn{2}{l}{ Model } \\
\cline { 2 - 3 } & III & IV \\
\hline Agricultural abundance $\times$ intensity & $0.298^{*}$ & $0.298^{*}$ \\
Skilled labor abundance $\times$ intensity & 0.096 & 0.077 \\
R\&D abundance $\times$ intensity & $0.071^{* *}$ & $0.072^{* *}$ \\
Environmental laxity $\times$ poll. intensity & $0.096^{* *}$ & $0.103^{* *}$ \\
\hline
\end{tabular}

Table 5 Marginal effects of country characteristics evaluated for the most intensive industries

\begin{tabular}{lcccc}
\hline \multicolumn{1}{l}{ Model } & & & \\
\cline { 2 - 4 } & III & IV & III $^{\prime}$ & IV $^{\prime}$ \\
\hline Agricultural abundance & $-6.365^{* *}$ & $-6.351^{* *}$ & $-0.131^{* *}$ & $-0.131^{* *}$ \\
Skilled labor abundance & $1.912^{*}$ & $1.909^{*}$ & $0.097^{*}$ & $0.097^{*}$ \\
R\&D abundance & $1.470^{* *}$ & $1.502^{* * *}$ & $0.182^{* *}$ & $0.185^{* * *}$ \\
Environmental stand. laxity & $1.565^{* *}$ & $1.408^{* *}$ & $0.110^{* *}$ & $0.099^{* *}$ \\
\hline
\end{tabular}

Notes: Columns $\left(\mathrm{III}^{\prime}\right)$ and $\left(\mathrm{IV}^{\prime}\right)$ present coefficients for normalized dependent and independent variables with unit SD

* Significant at $10 \%$ level; ** Significant at $5 \%$ level; *** Significant at $1 \%$

Table 3, are substituted in (1) and the dependent variable and independent variables are normalized. Expressed in this manner, the estimated coefficients are standardized and hence are comparable. In other words, we are measuring here the effects on the dependant variable in terms of standard deviation units. The resulting standardized coefficients (which Wooldridge 2009, p.188 refers to as "beta-coefficients") are independent of the scaling of the regressors and are reported in Table 4. That is, the choice for the unit of measurement for the country characteristics and industry attributes does not affect the coefficients reported in Table 4, and thereby the explanatory variables are put on equal footing.

Considering the standardized coefficients reported in Table 4, we note that the agriculture interaction remains the single largest determinant for industry location. The interaction between environmental policy and pollution intensity is of next greatest magnitude but is, in size, not much larger than the skilled labour and $R \& D$ interaction effects. The relative importance of the four interaction channels is robust across the four model specifications (although only standardized coefficients from Models III and IV are reported here).

The coefficients reported in Table 4 provide a general measure of the relative importance of the various interaction effects but we are also interested in the more specific strength of the interaction effects for the most intensive industries, that is, we may ask how strongly an abundance of skilled labor attracts the most skill-intensive industries, compared to how strongly a lax environmental policy attracts the most pollution intensive industries. For this, we use Eq. (3). We recall that the marginal effect on the industry share of a change in the country characteristic $j$ is proportional to the interaction coefficient $\beta^{j}$ as presented in Tables 3 and 4 , and to the distance between the industry's attribute level $y_{k}^{j}$ and the cut-off point $\gamma^{j}$. Thus, for industries above the cut-off point, an increase in the country characteristic will increase the industry share, while for industries below the cut-off point, an increase in the country characteristic will decrease the share. Table 5 presents the marginal effects of 
country characteristics on location for the most resource-intensive industries, that is, Eq. (3) evaluated at the maximum industry attribute level. We only report the HO interaction models (III and IV). For these models, we find that all four country characteristics are significant determinants for location of the most intensive industries, including skilled labour abundance.

Agricultural abundance does not have the expected positive effect on the location of the food processing industry. The sign is negative because the cut-off point is above the maximum attribute level observed in the sample, as discussed above. The magnitude of the three other country characteristic marginal effects appear similar in Columns (III) and (IV), but for a proper comparison, in Columns (III') and (IV'), we report the marginal effects using the standardized independent and dependent variables. Thus, it can be seen that in Models III and IV, a one standard deviation increase in the skilled labor supply increases the share of the most skilled-labor intensive industry (drugs and medicines) by about 0.1 times the standard deviation. The scale of the environmental policy effect for the dirtiest industry (industrial chemicals) is similar to this skilled labour effect, but the responsiveness of $R \& D$ intensive industries to a one standard deviation change of $R \& D$ abundance is far greater.

Figure 1 portrays in more detail the importance of a country's environmental policy on its share of particular industries. ${ }^{15}$ It is based on Eqs. (3) and(4) and uses results from Model III. It shows the marginal effect of environmental policy on the production share conditioned on the pollution intensity of the industry, with a $90 \%$ confidence interval added. The upward slope of the solid line represents the marginal effect of environmental standard laxity for different levels of pollution intensity, as depicted by Eq. (3). The figure shows the cut-off point 0.86 , where the solid line crosses the $x$-axis. For this level of pollution intensity, environmental laxity has no effect on location. For the industries to the left of this point a more stringent environmental policy increases the industry share. ${ }^{16}$ To the right of this point a more environmentally lax policy may attract a higher industry share. The $90 \%$ confidence intervals around the line permit us to evaluate at which values of pollution intensity environmental standard laxity has a statistically significant impact on production shares.

A lax environmental policy has a statistically significant positive effect on industry share when the pollution intensity level is above 1.86 , above which there is only one pollution intensive industry in our sample. On the right side of the figure, we find the pollution intensive industries such as Industrial Chemicals, (with the highest intensity, labelled ' $H$ '). On the left side of the figure, we find the majority of the industries that are less pollution intensive (the average and median value of pollution intensity are shown as 'A' and ' $M$ ', respectively). The 'cleanest' industry with the lowest pollution intensity level (Radio, TV and Communication Equipment) is shown by the point labelled ' $\mathrm{L}$ '.

The graph indicates that while the pollution haven effect is present its negative effect on industry location is significant only at relatively high levels of pollution intensity. At

\footnotetext{
15 This figure was constructed using the web-based tool of Preacher et al. (2003) (http://www.people.ku.edu/ $\sim$ preacher/interact $/ \mathrm{mlr}$ 2.htm), see also Brambor et al. (2006).

16 Though in this specific case, there are no industries where strict environmental policy has a significantly positive effect on their share, the model does not rule out this possibility. A possible explanation for such a positive relationship is that countries with strict environmental policies also have high levels of attractive characteristics such as good governance or low corruption levels, see Mulatu et al. (2004), Pellegrini and Gerlagh (2006b).
} 


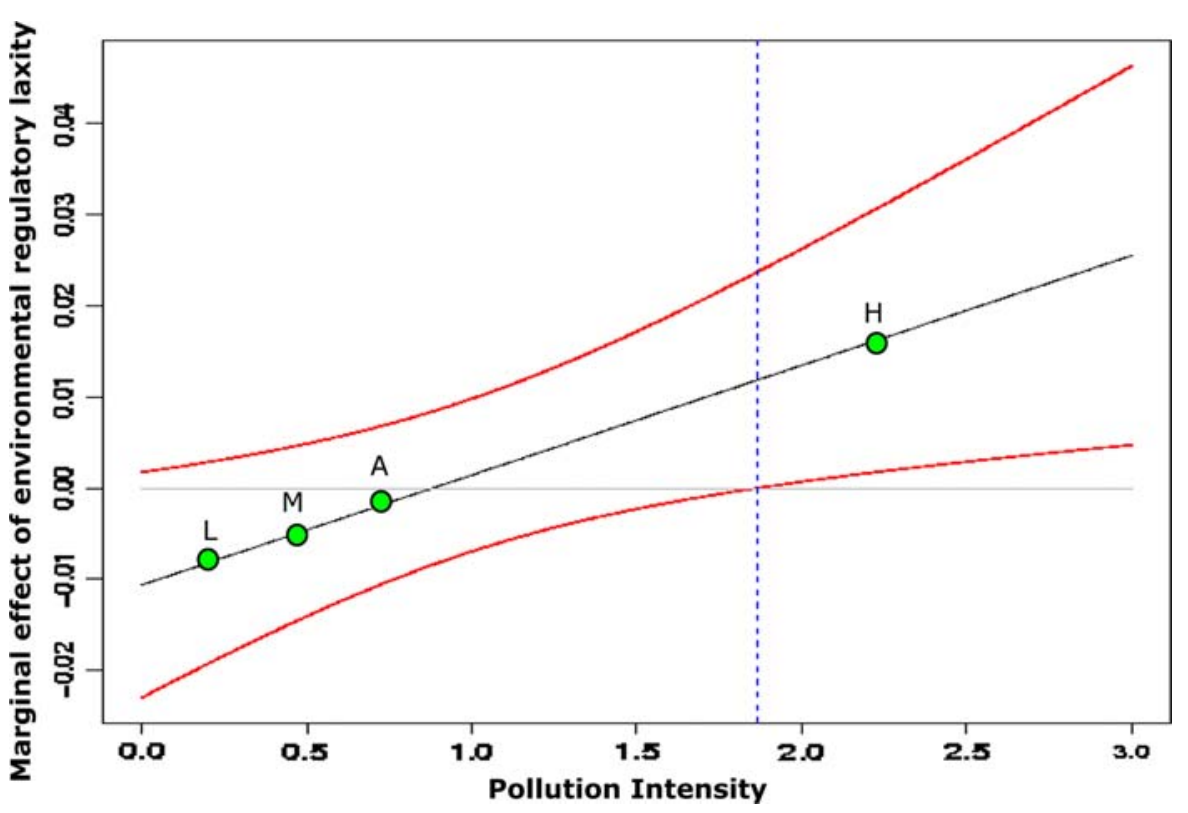

Fig. 1 The marginal effect of environmental standard laxity on production shares

Table 6 Actual, predicted and counterfactual production shares

\begin{tabular}{|c|c|c|c|c|}
\hline \multirow[t]{2}{*}{ Most intensive industry } & Agricultural input & Skilled labor input & $\mathrm{R} \& \mathrm{D}$ input & $\begin{array}{l}\text { Environmental } \\
\text { input }\end{array}$ \\
\hline & $\begin{array}{l}\text { Food, beverages } \\
\text { and tobacco }\end{array}$ & Drugs and medicines & $\begin{array}{l}\text { Radio, TV and } \\
\text { communication } \\
\text { equipment }\end{array}$ & $\begin{array}{l}\text { Industrial } \\
\text { chemicals }\end{array}$ \\
\hline
\end{tabular}

Actual shares (\%)

\begin{tabular}{lllll}
$\begin{array}{l}\text { 1. Most abundant } \\
\text { country and its } \\
\text { production share }\end{array}$ & Greece: 1.7 & Denmark: 1.7 & Sweden: 2.7 & Belgium:4.8 \\
$\begin{array}{c}\text { 2. Least abundant } \\
\text { country and its } \\
\text { production share }\end{array}$ & Belgium: 5.6 & Portugal: 1.3 & Greece: 0.3 & Finland: 1.0 \\
$\begin{array}{l}\text { Predicted shares }(\%) \\
\begin{array}{l}\text { 3. Most abundant } \\
\text { country }\end{array}\end{array}$ & 2.9 & 1.8 & & \\
$\begin{array}{l}\text { 4. Least abundant } \\
\text { Leastr }\end{array}$ & 4.8 & 1.3 & 4.1 & 7.3 \\
\hline
\end{tabular}

country

Counterfactual shares when countries would swap abundance values (\%)
5. Most abundant
5.2
1.2
1.7
country
1.9
1.1
2.0

country

$\%$ point difference between predicted and counterfactual shares
(3)-(5)
$-2.3$
0.6
2.4
4.2
(6)-(4)
$-2.1$
0.6
0.6
1.2

Note: Estimates are based on the regression with pollution intensity variable 1 
moderate levels of pollution intensity, the influence of environmental standard would be small compared to other forces, and at low levels of pollution intensity, strict environmental standards are not a deterrent at all.

Finally, in Table 6 we compare our estimated industry shares with observed shares and we calculate counterfactual industry shares: predicted shares if country characteristics (e.g. environmental policy) changed. We do this first by comparing estimated and actual industry shares for the most intensive industries in terms of each of agriculture, skills, R\&D and pollution intensity. In each case we compare these actual and predicted shares for the most and least abundant countries in the respective input. We then simulate these shares if, in each case, the most abundant country would become least abundant, and vice versa.

The comparison of the predicted and actual shares gives an idea of the fit of the model. A comparison of the counterfactual with the predicted shares answers the question how important the specific country characteristic is in determining the industry share. If the most abundant country in a particular factor were to have the level of endowment of the least abundant country what would be its share of production? The reverse also holds for the case of the least abundant country. With respect to the environmental factor input, we find that the model predicts a share of $7.3 \%$ of the most pollution intensive industry's production (Industrial chemicals) in the country with the most lax environmental standard (Belgium), compared with an actual share of $4.8 \%$. The model predicts a share of only $0.8 \%$ in the most environmentally stringent country (Finland) while the actual figure is $1.0 \%$.

If Belgium were to adopt the most stringent environmental regulation from Finland, the model predicts a decline of the share by more than half, that is, $4.2 \%$ point. If Finland were to copy the lax standards of Belgium, it would see its share increase by more than a factor two, that is, $1.2 \%$ point. A change in R\&D country characteristics has a similar effect in the sense that if Sweden would decrease its number of researchers per thousand to the level of Greece, its share of the Communication equipment industry is predicted to halve, while if Greece could copy Sweden's research abundance, it would see its share double. As both countries are fairly small, in absolute terms the change in industry shares would be less compared to the environmental policy change. A change in the abundance of skilled labor has somewhat less substantial consequences.

\section{Concluding Remarks}

This paper is an empirical analysis of the extent to which environmental regulation influences industry location in Europe vis-à-vis other location determinants, mainly the traditional HO factor endowment forces.

The analysis is based on a general empirical trade model. It has a distinctive feature in that it models the theoretically-emphasized joint role of country and industry characteristics in determining industry location. The model is applied to data on 16 manufacturing industries from 13 European countries. The Johnson-Neyman technique is used to address the interactive terms in the empirical model and to calculate regions of significance and confidence bands for evaluating the conditional effects.

This dataset covers countries with stringent environmental regulation like Finland and Sweden, and countries with relatively lax environmental regulation such as Greece and Belgium. With respect to industries, the dataset includes the most pollution intensive industries such as Industrial Chemicals as well as relatively clean industries such as Radio, TV \& Communication Equipment. 
The results indicate that the pollution haven effect can be uncovered, and the relative magnitude of this effect is about the same as that of other determinants of industry location. This might be interpreted as finding the pollution haven effect but failing to support the pollution haven hypothesis.

Specifically, we find in our sample that whereas an increase in the skilled labour supply increases the share of an industry with mean levels of characteristics, in contrast, increased environmental regulatory laxity does not result in an increased share of the 'average' industry. However, when the most polluting, rather than the average, industry is considered, increased environmental regulatory laxity does result in a higher proportion of this dirty industry locating there. The approach presented could be developed in a number of ways in future research, for example the issue of endogeneity of environmental policy in this framework, and the use of panel data for more robust estimation.

Open Access This article is distributed under the terms of the Creative Commons Attribution Noncommercial License which permits any noncommercial use, distribution, and reproduction in any medium, provided the original author(s) and source are credited.

\section{Appendix}

See Tables 7, 8, 9, 10 and 11.

Table 7 List of countries with the values of their characteristics

\begin{tabular}{|c|c|c|c|c|c|c|}
\hline Country & $\begin{array}{l}\begin{array}{l}\text { Population } \\
\text { (average, } \\
1990- \\
1994)\end{array}\end{array}$ & $\begin{array}{l}\text { Agricul- } \\
\text { tural } \\
\text { production } \\
\text { as \% GDP }\end{array}$ & $\begin{array}{l}\text { Secondary } \\
\text { and higher } \\
\text { education } \\
\% \\
\text { population }\end{array}$ & $\begin{array}{l}\text { Research } \\
\text { and } \\
\text { scientists } \\
\% \text { labor } \\
\text { force }\end{array}$ & $\begin{array}{l}\text { Market } \\
\text { potential }\end{array}$ & $\begin{array}{l}\text { Environ- } \\
\text { mental } \\
\text { regulation } \\
\text { strin- } \\
\text { gency }^{\text {a }}\end{array}$ \\
\hline Austria & 2.1 & 3.2 & 75.1 & 34 & 12303 & 67.9 \\
\hline Belgium & 2.7 & 1.9 & 60.6 & 53 & 13264 & 44.1 \\
\hline Denmark & 1.4 & 4.5 & 82.1 & 58 & 6627.8 & 67 \\
\hline Finland & 1.4 & 6.6 & 72.6 & 67 & 3642.1 & 80.5 \\
\hline France & 15.9 & 3.5 & 62.7 & 60 & 12380 & 65.8 \\
\hline Germany & 21.9 & 3 & 82.1 & 59 & 13073 & 64.2 \\
\hline Greece & 2.8 & 12.5 & 49.3 & 20 & 2335.7 & 53.1 \\
\hline Italy & 15.5 & 4.1 & 41.4 & 32 & 8715.1 & 54.3 \\
\hline Netherlands & 4.1 & 4 & 65.9 & 46 & 12840 & 66 \\
\hline Portugal & 2.7 & 7.3 & 23.8 & 31 & 3193.8 & 61.4 \\
\hline Spain & 10.6 & 5.4 & 35.1 & 32 & 4993.2 & 59.5 \\
\hline Sweden & 2.4 & 3.4 & 76.7 & 78 & 5810.5 & 77.1 \\
\hline UK & 15.7 & 2 & 55.3 & 50 & 12226 & 64.1 \\
\hline
\end{tabular}

Notes: Definitions of variables and data sources are presented in Table 1

${ }^{a}$ Environmental standard laxity is therefore the inverse of these figures 


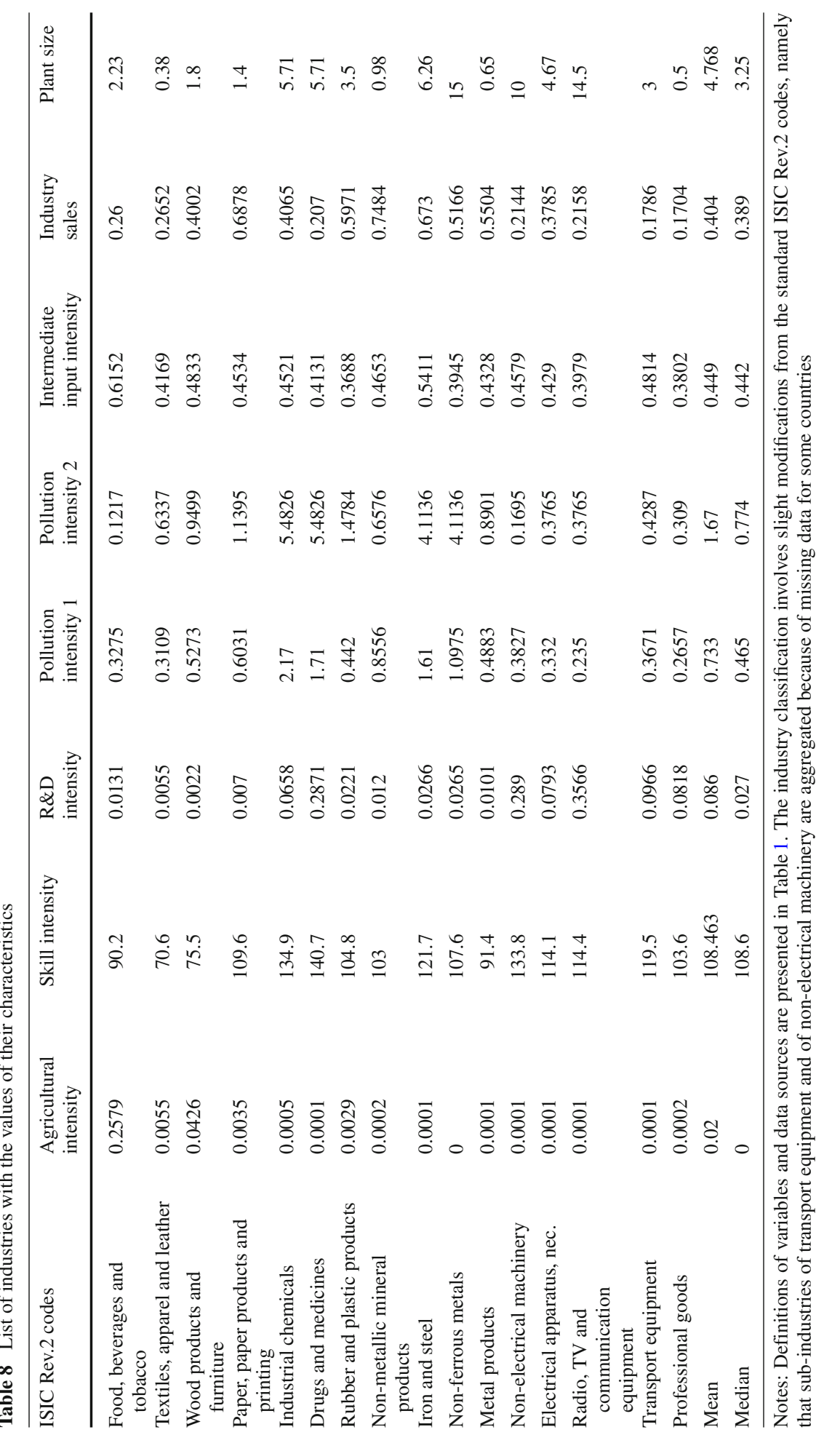


Table 9 Regression results of the determinants of industry location (with the stringency measure from Global Competitiveness Report 2001-2002)

\begin{tabular}{lcccc}
\hline Dependent variable: $\ln \left(s_{i k}\right)$ & \multicolumn{2}{l}{ Model } & & \\
\cline { 2 - 5 } & I & II & III & IV \\
\hline Size variable & $1.06^{* * *}$ & $1.06^{* * *}$ & $1.07^{* * *}$ & $1.07^{* * *}$ \\
Population & & & & \\
Interaction channels $\left(\beta^{j}\right)$ & $34.48^{* * *}$ & $34.49^{* * *}$ & $41.56^{* * *}$ & $43.17^{* * *}$ \\
Agricultural abundance $\times$ intensity & $2.92^{* *}$ & $2.88^{* *}$ & $3.25^{* *}$ & $3.09^{* *}$ \\
Skilled labor abundance $\times$ intensity & $3.23^{*}$ & $3.41^{*}$ & $3.60^{*}$ & $3.94^{* *}$ \\
R\&D abundance $\times$ intensity & $1.98^{* *}$ & $0.67^{* *}$ & $2.15^{* *}$ & $0.67^{* *}$ \\
Environmental laxity $\times$ poll. intensity & -3.29 & -2.96 & & \\
Market potential $\times$ sales to industry & -4.96 & $-6.14^{*}$ & & \\
Market potential $\times$ intermediate input use & $0.23^{*}$ & $0.27^{* *}$ & & \\
Market potential $\times$ plant size &
\end{tabular}

Notes: * Significant at 10\% level; ** Significant at 5\% level; *** Significant at 1\%

Table 10 Marginal effects of country characteristics evaluated for the most intensive industries (with the stringency measure from Global Competitiveness Report 2001-2002)

\begin{tabular}{lcc}
\hline & Model & \\
\cline { 2 - 3 } & III & IV \\
\hline Agricultural abundance & -1.89 & -1.54 \\
Skilled labor abundance & $2.41^{*}$ & $2.26^{*}$ \\
R\&D abundance & $1.20^{* *}$ & $1.29^{* * *}$ \\
Environmental stand. laxity & 0.99 & 0.44 \\
\hline
\end{tabular}

Notes: * Significant at $10 \%$ level; ** Significant at 5\% level; *** Significant at 1\%

Table 11 Interaction effects using instruments

\begin{tabular}{|c|c|c|c|c|}
\hline \multirow[t]{2}{*}{ Dependent variable: $\ln \left(s_{i k}\right)$} & \multicolumn{4}{|l|}{ Model } \\
\hline & III & IV & III & IV \\
\hline \multicolumn{5}{|l|}{ Size variable } \\
\hline Population & $0.98^{* * *}$ & $0.98^{* * *}$ & $1.02^{* * *}$ & $1.02^{* * *}$ \\
\hline \multicolumn{5}{|l|}{ Interaction channels $\left(\beta^{j}\right)$} \\
\hline Agricultural abundance $\times$ intensity & $37.7^{* * *}$ & $38.4^{* * *}$ & $42.6^{* * *}$ & $44.1^{* * *}$ \\
\hline Skilled labor abundance $\times$ intensity & $2.45^{*}$ & $2.32^{*}$ & $3.11^{* *}$ & $2.92^{* *}$ \\
\hline R\&D abundance $\times$ intensity & $4.26^{* *}$ & $4.53^{* *}$ & $3.70^{*}$ & $4.05^{* *}$ \\
\hline Environmental laxity $\times$ poll. intensity & $2.03^{* *}$ & $0.62^{* *}$ & $2.09^{* *}$ & $0.64^{* *}$ \\
\hline Instrumented variable & \multicolumn{2}{|c|}{$\begin{array}{l}\text { Environmental sustainability } \\
\text { index (2001) }\end{array}$} & \multicolumn{2}{|c|}{$\begin{array}{l}\text { Environmental regulation } \\
\text { stringency }(2001)\end{array}$} \\
\hline
\end{tabular}


Table 11 continued

\begin{tabular}{|c|c|c|}
\hline \multirow[t]{2}{*}{ Dependent variable: $\ln \left(s_{i k}\right)$} & \multicolumn{2}{|l|}{ Model } \\
\hline & III & III \\
\hline \multirow{3}{*}{$\begin{array}{l}\text { Instruments (only instruments with } \\
\text { significant coefficients are used) }\end{array}$} & Corruption $(1995)^{* * *}$ & Corruption $(1995)^{* * *}$ \\
\hline & Urbanization $(1997)^{* *}$ & Income $(1992)^{* * *}$ \\
\hline & & Schooling $(1990)^{* *}$ \\
\hline$R^{2}$ adj first-stage & $50 \%$ & $94 \%$ \\
\hline
\end{tabular}

Notes: * Significant at $10 \%$ level; ** Significant at $5 \%$ level; *** Significant at $1 \%$

\section{References}

Antweiler W, Copeland B, Taylor S (2001) Is free trade good for the environment? Am Econ Rev 91:877-907

Bauer DJ, Curran PJ (2005) Probing interactions in fixed and multilevel regression: inferential and graphical techniques. Multivar Behav Res 40:373-400

Becker RA, Henderson JV (2001) Effects of air quality regulations on polluting industries. J Polit Econ 108:379-421

Brambor T, Clark L, Golder M (2006) Understanding interaction models: improving empirical analyses. Polit Anal 14:63-82

Chintrakarn P, Millimet DL (2006) The environmental consequences of trade: evidence from subnational trade flows. J Environ Econ Manage 52:430-453

Cole MA, Elliott RJR (2003a) Determining the trade-environment composition effect: the role of capital, labor and environmental regulations. J Environ Econ Manage 46:363-383

Cole MA, Elliott RJR (2003b) Do environmental regulations influence trade patterns? Testing old and new trade theories. World Econ 26:1163-1186

Cole MA, Elliott RJR, Shimamoto K (2005) Why the grass is not always greener: the competing effects of environmental regulations and factor intensities on US specialization. Ecol Econ 54:95-109

Copeland B, Taylor S (1994) North-South trade and the environment. Q J Econ 109:755-787

Copeland B, Taylor S (1995) Trade and transboundary pollution. Am Econ Rev 85:716-737

Copeland B, Taylor S (2003) International trade and the environment: theory and evidence. Princeton University Press, Princeton

Ederington J, Levinson A, Minier J (2004) Trade liberlization and pollution havens. Adv Econ Anal Pol 4 (Article 6)

Fullerton D (2006) The economics of pollution havens. Edward Elgar, Cheltenham

Greenstone M (2002) The impacts of environmental regulations on industrial activity: evidence from the 1970 and 1977 clean air acts and the census of manufactures. J Polit Econ 110:1175-1219

Huitema B (1980) The analysis of covariance and alternatives. Wiley, New York

Jaffe AB, Peterson SR, Stavins RN (1995) Environmental regulation and the competitiveness of United States manufacturing — what does the evidence tell us? J Econ Lit 33:132-163

Javorcik B, Wei S (2004) Pollution havens and foreign direct investment: dirty secret or popular myth? Contrib Econ Anal Pol 3 (Article 8)

Jeppesen T, List JA, Folmer H (2002) Environmental regulation and new plant location decisions: evidence from a meta-analysis. J Reg Sci 42(1):19-49

Keller W, Levinson A (2002) Pollution abatement costs and direct foreign investment inflows in the United States. Rev Econ Stat 84:691-703

Krugman P, Venables AJ (1995) Globalization and the inequality of nations. Q J Econ 110:857-880

Leamer E (1984) Sources of international comparative advantage: theory and evidence. MIT, Cambridge

Levinson A, Taylor MS (2008) Unmasking the pollution haven effect. Int Econ Rev 49: 223-254

List JA, Co CY (2000) The effects of environmental regulations on foreign direct investment. J Environ Econ Manage 40:1-20

List JA, McHone WW (2000) Measuring the effects of air quality regulations on "dirty" firm births: evidence from the neo- and mature-regulatory periods. Pap Reg Sci 79:177-190

Low P, Yeats A (1992) Do 'dirty' industries migrate? In: Low P (ed) International trade and the environment. World Bank, Washington DC, pp 89-103 
Midelfart-Knarvik KH, Overman HG, Venables AJ (2000a) Comparative advantage and economic geography: estimating the location of production in the EU. Centre for economic policy research discussion paper no. 2618

Midelfart-Knarvik KH, Overman HG, Redding SJ, Venables AJ (2000b) The location of European industry, economic papers no. 142. European commission. D-G for economic and financial affairs, Brussels

Millimet DL, List JA (2004) The case of the missing pollution haven hypothesis. J. Regul. Econ. 26:239-262

Mulatu A, Florax R, Withagen C (2004) Environmental regulation and international trade: empirical results for Germany, the Netherlands and the US, 1977-1992. Contrib Econ Anal Pol 3 (Article 5)

Pellegrini L, Gerlagh R (2006a) Corruption and environmental policies: what are the implications for the enlarged EU? Euro Environ 16:139-154

Pellegrini L, Gerlagh R (2006b) Corruption, democracy and environmental policy: an empirical contribution to the debate. J Environ Devel 15:332-354

Pratten C (1988) A survey of the economies of scale. In Commission of the European Communities: Research on the Costs of non-Europe, 2: Studies on the Economics of Integration

Preacher K, Curran P, Bauer D (2003) Simple intercepts, simple slopes, and regions of significance in MLR 2-way interactions. Available from http://www.psych.ku.edu/preacher/interact $/ \mathrm{mlr} 2 . \mathrm{htm}$

Raspiller S, Riedinger N (2008) Do environmental regulations influence the location of french firms. Land Econ 84(3):382-395

Reinaud J (2004) Industrial competitiveness under the European Union Emissions Trading Scheme. International Energy Agency Information Paper

Taylor S (2004) Unbundling the pollution haven hypothesis. Adv Econ Anal Pol 4 (Article 8)

van Soest DP, List JA, Jeppesen T (2006) Shadow prices, environmental stringency, and international competitiveness. Eur Econ Rev 50:1151-1167

Venables AJ (1996) Equilibrium locations of vertically linked industries. Int Econ Rev 37:341-359

Wolfe R (2004) Crossing the river by feeling the stones: where the WTO is going after Seattle, Doha and Cancun. Rev Int Polit Econ 11:574-596

Wooldridge J (2009) Introductory econometrics: a modern approach, 3rd edn. Thomson South-Western

Xing YO, Kolstad CD (2002) Do lax environmental regulations attract foreign investment? Environ Resour Econ 21:1-22 